原

体表面電位図より求めた心室興奮過程の心双極子性,

\title{
陳旧性前壁心筋梗塞による影響
}

\author{
昭和大学藤が丘病院循環器内科（主任 春見建一教授）
}

兼坂茂

\section{CARDIAC DIPOLARITY OF VENTRICULAR EXCITATION SEQUENCE CALCULATED FROM BODY SURFACE POTENTIAL MAP ; OLD ANTERIOR MYOCARDIAL INFARCTION}

Shigeru KANESAKA, MD

Division of Cardiology, Showa University Fujigaoka Hospital

(Director; Professor Kenichi Harumi)

\begin{abstract}
概要 体表面電位図より瞬時ごとの心双極子性を計算し，陳旧性前壁心筋梗塞患者と正常者の それと比較険討した。 また，心室内興奮后播過程の二次元シュミレーションモデルを作成して， 本法の妥当性を推定した，対象は正常者26例，前壁心筋梗塞患者25例である．梗塞の部位と大 きさは ${ }^{201} \mathrm{Tl}$ 心筇シンチグラムより分け，梗塞範囲が左室の $40 \%$ 末满を前壁群16例，それ以上を 広範前壁群 9 例とした，双極子性の示標としては，体表面電位分布を単一双極子で近似しえな い成分を残渣として経時的に求めた，その結果，前壁梗塞群では正常群に比し，QRSの23土5 msecで残椬はきわめて有意な高值を示し $(\mathrm{p}<0.001)$ ，上り多双極子性が示唆された，㽻範前壁 梗塞群では正常群に比し，QRSの $45 \pm 7 \mathrm{msec}$ で残渣は非常に有意な低值を示し（p<0.01）単 一双極子性が示唆された，二次元シュミレーションでわ，梗塞による双極子性の変化は残潜曲 線上に臨床例と同様の傾向として表われ，本法の信頼性が確かめられた。筋梗塞の大きさと

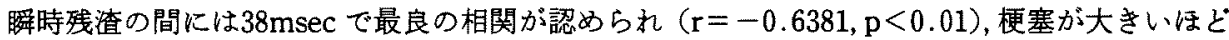
単一双極子性が高いことが示唆され，本法により心筋梗塞の大きさが推定できる可能性が示さ れた。
\end{abstract}

Taccardi ${ }^{11}$, Horan $^{2)}$, Spack $^{31}$ らにより心室興奮 過程には体表面電位図上, 同時に複数の極大・極 小が出現する，すなわち，単一双極子では十分に 表現できない非双極子成分の存在が示されてい る、また，GabarとNelson ${ }^{4}$ 以来，経時的に双極子 の位置らが求められてきているが，これらの多双 極子性扣よびmoving dipoleの手法の臨床応用は ほとんどされていない，そこで，我々はmoving dipoleを計算し，そのdipoleでは表現できない非 双極子成分を残渣 Residueとして経時的に算出

〔昭和59年7月 10 日受稿〕
し，逆問題の立場から正常者について報告した $か^{6}$ ，今回，本法を陳旧性心筋梗塞患者の体表面電 位図に応用し，正常者と比較検討したので報告す る.

\section{対象と方法}

対象は正常者26例扣よび陳旧性前壁心筋梗塞患 者25例である．正常者は25～35才の男性病院関係 者で，心疾患の既往はなく，理学的所見，標準 12 誘導心電図ともに正常範囲内であつた。心筋梗塞 例は，急性期に典型的な胸痛の病歴, 特徵的な標 準12誘導心電図上の变化，血清酵素学的变化を認 めた陳旧性心筇梗塞患者で,44〜79才（平均60.6士 
$9.6 才) の$ 男性 22 人，女性 3 人である，梗塞巣の部 位と大きさは，Siemens社製ガンマカメラ(PhoGamma LEM ZLC System Model 6580) を用 い201Tl心筋シンチグラフィが施行され，多方向撮 影像から 2 人の専門医により個別に決定された。 梗塞巣は前壁を主体とし，中隔，側壁または下壁 を含み，その大きさは最大RI集積欠損部の外周囲 と左室周囲長の比率で，40\%未満の16例を前壁梗 塞群，40\%以上の 9 例を広範前壁梗塞群と分けて 検討した.

体表面電位図は ${ }^{201} \mathrm{Tl}$ 心筋シンチグラフィとほ ぼ同時期に，我々の開発した装置で記録された7).

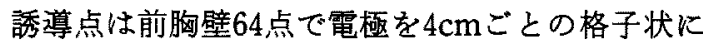
配列し，電極の最上例は鎖骨直下とした。各点で の電位は洞調律時に, Wilson中心電極を不関電極 とし，帯域幅 $0.5 \sim 500 \mathrm{~Hz}$ ，利得 $60 \mathrm{~dB}$ を持つ心電図 用アンプを用いて，2msecごとに同時記録し，64 点からのデータはマルチプレクサーを介して順次 $\mathrm{AD}$ 変換され，8ビットのデジタル量としてフ ロッピーディスクに収録された。電極や増幅器の 特性に起因するドリフトやオフセットはデータ解 析の前に除去され，ゼロ電位はTQ部分より決定 した。この修正データを空間的補間計算などマイ クロコンピュータ（NOVA 4/s）で処理した後,

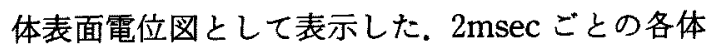
表面電位図は等電位線の間隔を $\pm 2.5 \mathrm{mV} / 8$ と し, $\pm 0.3125 \mathrm{mV}$ 以下をぜ口電位領域として黒色 で，正電位領域を白色で，負電位領域を白地に黒 の斑点の部分として表示した，心室興奮過程にお ける心起電力の主双極子の位置と成分及び非単一 双極子成分 (Residue) は，Okamotoらの方法")

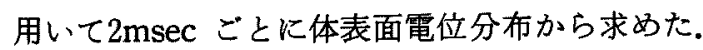
この方法の詳細な原著に譲るが，その原理は体表 面の前面を無限平面とし, 人体を導電率一定の半 無限空間とした時, 体内のある点に仮定した双極 子による体表面上の電位分布は，鏡像法を用いて 計算され得る。誘導点 $i$ の位置に㧍ける実測電位 を $\varphi$ meas. $i$ とし, それに対応する計算上の電位を $\varphi$ cal. 法した時, Sをproximity functionとし, 図1の1) 式で示すように, 各誘導点における両
1) Instantaneous Dipole Moment from Body Surface Potential $s(\vec{r}, \vec{d})=\sum_{r=1}^{N}(\text { cpmeas. } i-\varphi \text { cal. } i)^{2}$ $S:$ Proximity function $(\vec{r}:$ 位置, $\vec{d}:$ 成分) omeas. $i: i$ の位置における実測電位 ccal. $i: i$ の位圆における計算上の電位

2) Ratio of Nondipalar Component (Residue)

$$
\sqrt{\frac{\sum(\rho \text { meas. } i-\varphi \text { cal. } i)^{2}}{\sum \varphi \text { meas. } i^{2}}}
$$

3) Root Mean Square (RMS)

$$
\sqrt{\frac{\sum \text { ipmeas. } i^{2}}{n}}
$$

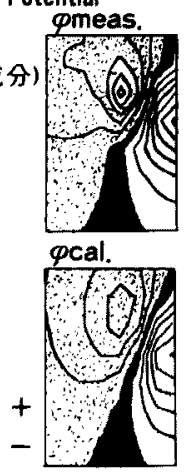

図 1。体表面電位分布上り心双極子，残淖を求める式 右上の体表面電位図はある瞬時の実湘電位分布を示 し, 右下の体表面電位四はその瞬時にProximity functionが最小になる主双極子の計算上の電位分布を示 す.すなわち，残滈 (Residue) とは上下の 2 図の差を 示す值である，また，瞬時ごとの体表面電位の棇和を Root Mean Square (RMS) で表わした.

者の電位の 2 乗誤差が最小になるよ5に双極子の

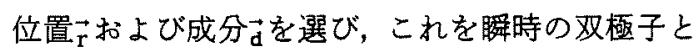
する，すしすべての体表面電位分布が単一双極子 で代表し得れば，実測電位と計算上の電位は等し くなりS=0となる．Sが大きくなれぱ，それだけ 非単一双極子性が増大寸る。すなおち, 複数の双 極子が存在することになる。起電力の非単一双 極子性の定量的な表現法として，図 1の2)式の ように定義された量；残渣Residueを用いた。こ れは測定された体表面電位分布の中に単一双極子 で表現し得ない電位成分が，振幅比で何\%あるか を示すことになる．むた，心電困との時間的関係 を示すため，瞬時ごとの体表面電位の総和をRoot Mean Square (RMS) で算出した（図 1 の式). QRSの開始はRMS電位が連続的に漸増する初め の時点とし，QRSの終末はRMS電位が連続的に 淵減する終りの時点とした。本研究ではこのQRS 幅が $100 \mathrm{msec}$ までを対象とし，正常群26例で平均 $87.6 \pm 8.1 \mathrm{msec}$, 梗塞群 25 例で平均 $82.9 \pm 8.8$ $\mathrm{msec}$ と有意差は認められなからた。

さらに本法を臨床応用する事の妥当性を検討す るために, 二次元心室興奮伝播のシュミレーショ ンモデルを作成し臨床例と比較した。二次元心筋 


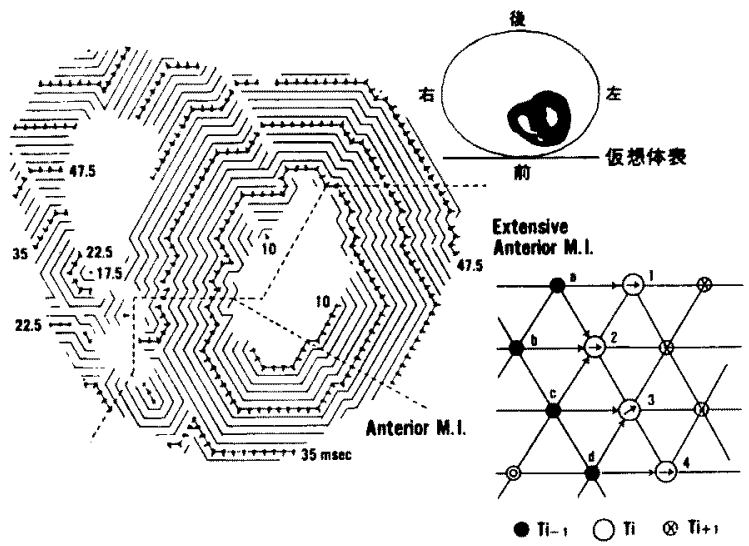

図2，2次元心跭モデル

2 次元心筋モデルは左図のよらな興幂波面を持つ心 臟横断面として作成された，時刻 Ti前後の各格子点の 興禽規則及び双極子の方向決定については（図右下） 本文中で述べた，人体の横断面は棈円でモデル化し， 棈円上の前面64点における体表面電位が，仮想体表上 にあると見なして主双極子は計算された。，心筋梗塞 （M.I）設定時には，破線内の格子点が興艋不能として 計算された。

モデルはDurrerらの報告9)を基に心葴横断面を， $50 \times 50$ のトリックスを用い，各格子点は以下の 興奮規則に芫つて興奮すると仮定する（図 2 右 下）１）時刻Ti李でに與奮していない，2）時刻 $T_{1-1}$ に抦いて，隣接する格子点の少なくとも一つ が興奮している．3）興奮可能な格子点である．4） 時刻Tiに興奮していれば，時刻T $1+1$ には興奮を終 える。次に，興奮波面上に発生する電気二重層を シュミレートするために，興奮した格子点が発生 する双極子について規定する１）興奮している間 たけ起電力を生ずる，2）双極子の方向は，この格 子点を興奮させた格子点と，この格子点を結ぶべ クトルの合成ベクトルの方向である.3）合成ベク トルがゼロであれば,格子点は起電力を生じない

4）合成へクトルがゼロでなければ, 幾つかの格子 点から興奮が伝播して来たかによらず，双極子の 大ささは常に一定である。こうした格子点を並べ て図 2 左の様な心矨モデルを作成した。図上, 2.5 msec ごとに同時興奮する格子点を実線で結び,

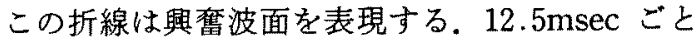
の各格子点からの短い線は，その格子点加発生
する双格子の方向を示す. Durrerらの心室興奮過

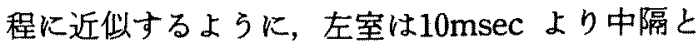
前側壁心内膜側より同時に発火させ，右室は 17.5 $\mathrm{msec} よ り$ 右室壁中央やや前側の心内膜より発 火，続いて右室前壁側の 2 力所で発火させ， 80 msec までの伝播をモデル化した，梗塞を設定す る際には破線内の格子点が興奮不能として，興奮 波面に変化をつけた。人体の横断面は棈円でモデ ル化し，図 2 右上の様な解剖学的に近似した位置 で棈円内に心臓横断面を定め，棈円上の前面64点 における体表面電位を算出した。体表面電位より 心双極子を求める際は，臨休例で用いた方法と同 様に，64の誘導点が棈円前縁の接線上（仮想体表 上）にあると見なして，正常および梗塞設定時の 主双極子を計算し，非双極子成分Residueを求め た.さらに，本計算法の理解のために図 8 では,

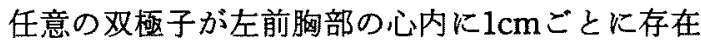
すると仮定した際，各位置で計算されるResidue を求め，双極子の位置による影響を検討した。

\section{結果}

\section{1. 正常}

正常群の 1 例のResidue, RMS電位，体表面電 位図を図 3 左に示した. ResidueはQRS開始時に 40\%以上の高值を示したが，これは体表面電位が 低値のための雑音の影響と考えられた。その後， Residueは急減し20msec で第 1 のピークを示し, RMS電位曲線上に結節を認めた。体表面電位図上 では負電位領域が 2 つに分かれて，正電位領域の 波面はやや複雑な等電位線を示した，その後， Residueは26〜28msec で最低值を示し，28msec の体表面電位図では右上に負電位領域，左に正電 位領域があり等電位線はほぼ同心円状をなし，単 一双極子性が高いことは明らかであつた. その後, Residueは上昇を続け50msec で第 2 のピークを 形成した. RMS電位曲線上は深い谷状の電位の低 下を示し，体表面電位図では負電位領域の一部の 下方への張り出しが明らかとなつた。

正常群26例の瞬時ごとのResidueの平均值と RMS電位の平均値を経時的に図 4 左に示した。 ResidueはRMS電位曲線上の前半のほぼ中央22 


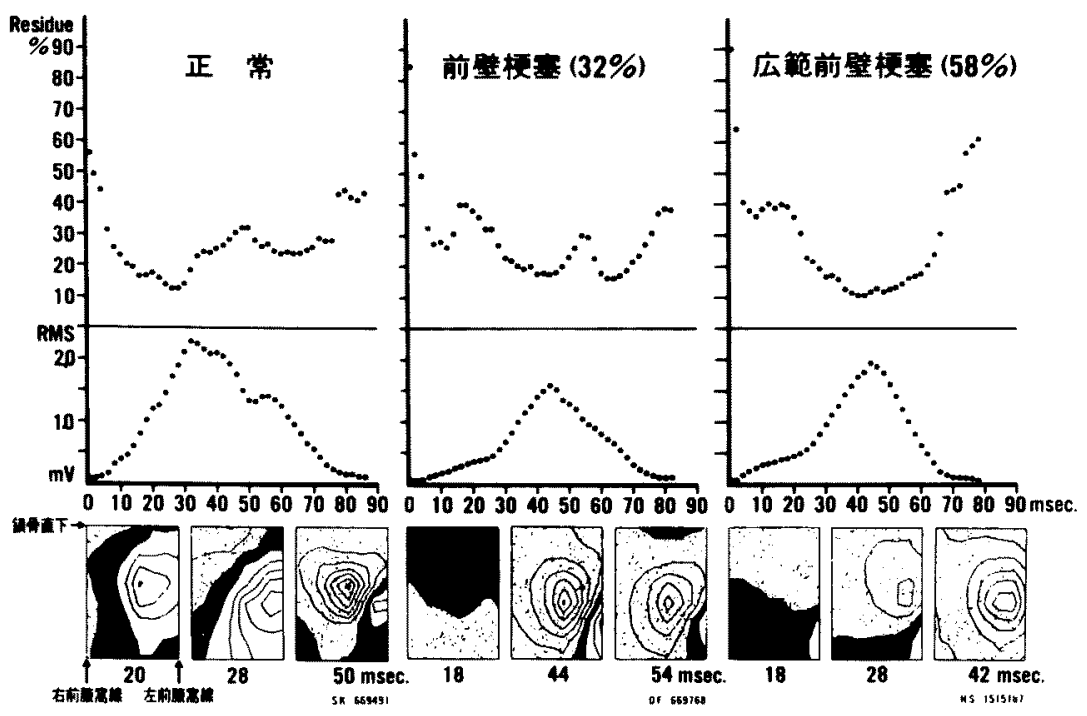

図 3.臨床例（TI\%）

各群の臨例に扣けるQRS間のResidue（上段），RMS電位（中段），実測体表面電 位図 (下段) 劣示す、日は0.3125mV以下のゼ口電位領域，口は正電位領域，は負 電位領域を示す。

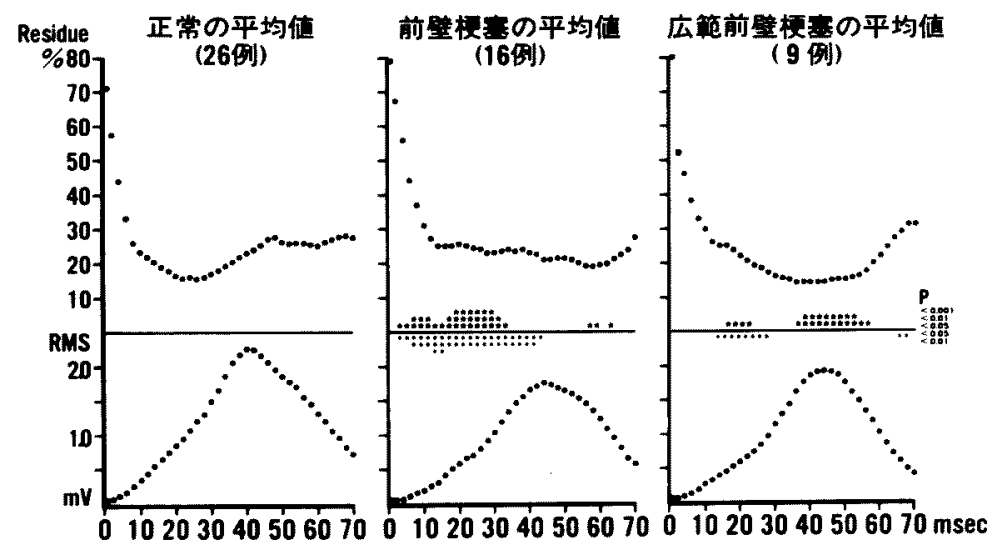

图 4. 臨床例の平均

臨床各群の平均Residue（上段）と平均RMS䉓位（下段）を示す．瞬時ごとに正常 群と梗塞群の間で有意差検定をおこなつた。前壁梗塞群のResidueはQRSの18２8 $\mathrm{msec}$ で危険率 $\mathrm{p}<0.001\left(\begin{array}{c}\star \\ \star\end{array}\right)$ の有意差を認め，広範前壁梗塞群では38～-52msecで危 険率 $\mathrm{p}<0.01$ ( $)$ の有意差を認めた。

msec で15.6土0.4\%の最低值を示し，48msec で は27.6士11.4\%とピークを形成し，その後は横ば いであつた。図 3 左で認めたResidueの前半の小 ピークは各症例で存在したが，平均值では不明と なつた。これらの所見は前報と同様であつた。

\section{2. 前壁梗塞}

前壁梗塞群の 1 例のResidue, RMS電位, 体表 面電位図を図 3 中央に示した。 Residueは正常例 と異なり10msec 前後で谷を形成し，18msecで第 1 のピークを示した，体表面電位図上ではゼロ電 
位領域と負電位領域との境界が複雑であつた。そ の後, $44 \mathrm{msec}$ 前後ではResidueは $20 \%$ 以下の低值 を示しRMS電位はピークに達した。体表面電位図 では負電位領域が主体をなし比較的きれいな同心 円を形成し，正電位領域は左下に小さく存在した。 $54 \mathrm{msec}$ ではResidueは第 2 のピークを示し，体表 面電位図では負電位領域の広がりの不整が明らか となり，正電位領域は左下にわずかに存続してい た.さらに, $62 \mathrm{msec}$ 前後ではResidueは再び低下 し最低值を示した，体表面電位図では負電位領域 が下半分を占め, ゼロ電位領域との境界は直線状 であつた。

前壁梗塞群16例の瞬時ごとのResidueの平均值 とRMS電位の平均値を経時的に図 4 中央に示し た. Residueは41msec を境として，その前半で正 常群より高值, その後半で比較的低值を示した。 $20 \mathrm{msec}$ では正常群と異なり $25.2 \pm 7.4 \%$ とピー クを形成し,正常群の $16.5 \pm 4.6 \%$ に比し極めて有 意な高值を示し，18～28 $\mathrm{msec}$ で危険率 $\mathrm{p}<0.001$

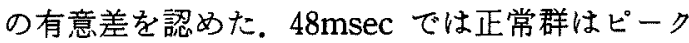
を形成したが，前壁梗塞群は $22.0 \pm 7.5 \%$ と比較的 低值を示し有意差はなかつた. RMS電位の平均值 は前半の6 40msec で正常群より明らかに有意

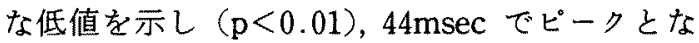
ク，そのピークは正常より $4 \mathrm{msec}$ 遅れていた. ResidueがQRS前半の $23 \pm 5 \mathrm{msec} て ゙$ 極めて有意な 高値を示した事は，この時点では正常に比し多双 極子性がより高いことを示唆していると考学られ た。

\section{3. 広範前壁梗塞}

広範前壁梗塞群の 1 例の Residue, RMS電位, 体表面電位図を図 3 右に示した. Residueは4 20 msec で約 $40 \%$ の比較的高値を示し，18 $\mathrm{msec}$ の体 表面電位図ではゼ口電位領域と負電位領域との境

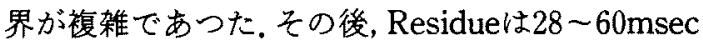
で20\%以下の低值を示し，その間には正常例や前 壁梗塞例で認められたピークは存在しなかつた。 $28 \mathrm{msec}$ の体表面電位図は主に負電位領域で占め られたが，ゼ口電位との境界は滑らかで，正電位 領域は左下にわずかに存在した. RMS電位のピー

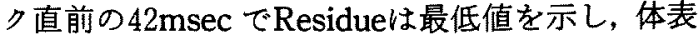
面電位图は等電位線がほ注同心円状をなす負電位 領域のみで占められた。

広範前壁梗塞群 9 例の瞬時ごとのResidueの平 均值とRMS電位の平均值を経時的に図 4 右に示 した，Residueは $29 \mathrm{msec}$ を境として，その前半で 正常群より高値，その後半で低值を示した， 20 msec では $22.0 \pm 5.3 \%$ と正常群の $16.5 \pm 2.1 \%$ に 比し有意に高値を示し，18～22msec で危険率 $\mathrm{p}<$

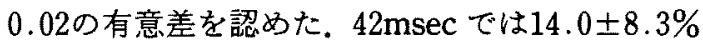
と正常群の $24.0 \pm 6.9 \%$ に比し明らかに有意な低 値を示し，38～52msec で危険率 $\mathrm{p}<0.01$ の有意差 を認めた. RMS電位の平均値は前半の20 26 msec で正常群より有意に低值を示し $(\mathrm{p}<0.02)$, $44 \mathrm{msec}$ でピークとなり，そのピークは正常より4 msec 遅れていた. ResidueがQRS中頃の $45 \pm 7$ msec で明らかに有意な低值を示した事は，この 時点では正常に比し単一双極子性がょり高いこと を示唆していると考えられた。

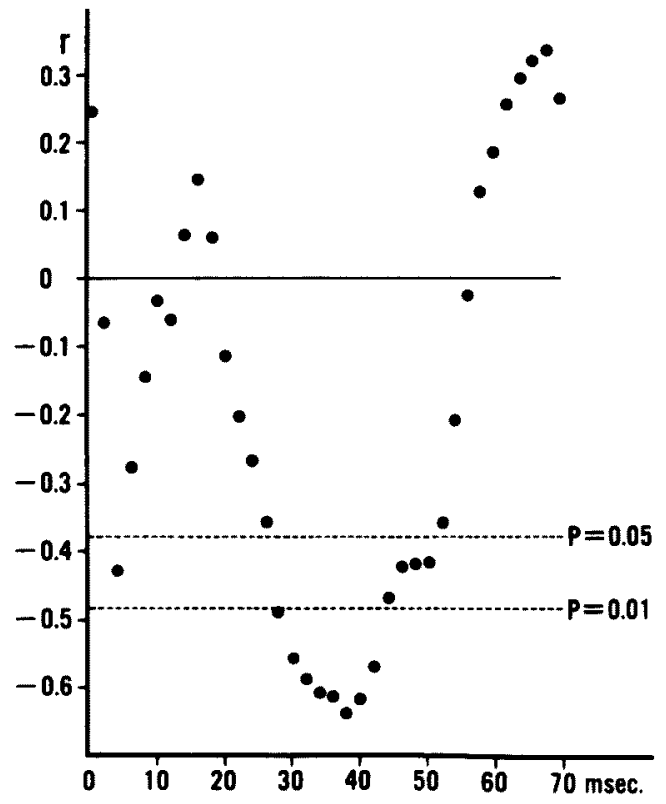

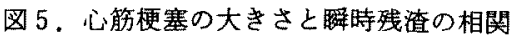
心筋梗塞群25例の梗塞の大きさと, QRS間の瞬時ご との残浩 (Residue) との相関俰数を経時的に求めた. $38 \mathrm{msec}$ て $\mathrm{r}=-0.6381(\mathrm{p}<0.01)$ 之最良の負の相関を 認めた。 


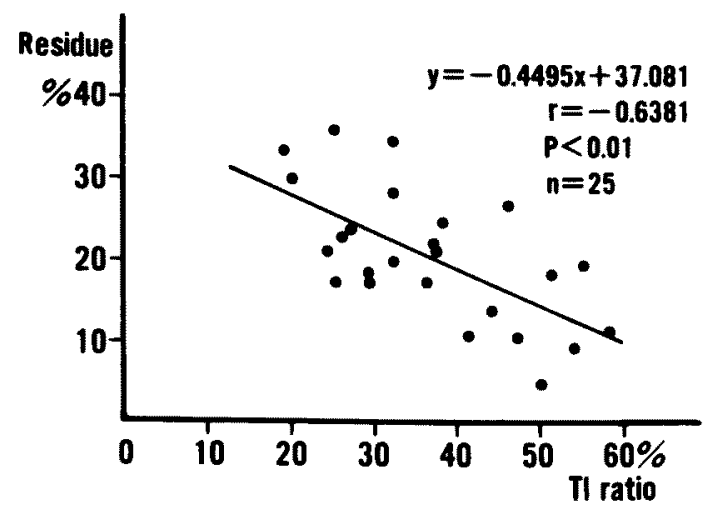

図6、心筋梗塞の大きさと38msecの残渣 心筇梗塞群25例の梗塞の大きをと，QRS $38 \mathrm{msec} の$ 残洫 (Residue) との間には負の相関が認められ，広範 な梗塞ほと残洫は低值を示し単一双極子性が高いこと が示唆された。

\section{4. 梗塞の大きさと瞬時残渣}

前述の図 4 に示されたようにResidueの平均值 は, 梗塞群が正常群に比しQRSの前半で高く, 後 半で低い結果を得た，特に，前壁梗塞群では前半 に極めて有意な差を，広範前壁梗塞群では後半に 明らかな有意な差を認めた。よつて，梗塞の大き さと瞬時Residueの間で，梗塞全25例のいずれの 時間点のResidueが最も関連が深いか検討した。

図 5 に梗塞25例の大きさと瞬時ごとのResidueの 相関係数を経時的に図示した。 その結果，QRSの $38 \mathrm{msec}$ で最も相関が高く, r= $=0.6381$ の相関係 数を示し，両者間には明らかな負の相関を認めた $(\mathrm{p}<0.01)$. 図 6 の様に，広範な梗塞ほど $38 \mathrm{msec}$ のResidueは低值を示し，単一双極子性が高いこ とが示唆された。

5. 二次元心室興蓄伝播シュミレーション

二次元モデルにおける正常, 前壁梗塞, 広範前 壁梗塞のResidue, RMS電位を算出し，経時的な 変化を図 7 に示した。

\section{1) 正常}

図 2 で示した正常心室興奮過程のシュミレー ションの結果を図 7 左に示した。左室の興奮開始 から10 14msec では主な興奮波面は左室前壁側 に存在し, Residueは $12 \%$ 前後の值を示した. 17.5 msec では興奮波面は中隔前壁側之右室中央に存
在し, Residueは $24 \%$ に増大乙第 1 のピークを示 した. $20 \mathrm{msec}$ では興偪域は左室前壁から中隔ま での大きなつの波面となり，Residueは15.7\% まで低下した。 22.5msec で右室のbreak through が起こり，22.5 27.5msec で左室の興奮は閉曲 面となるため, Residueは右室の 3 力所からの興 奮を反映して20\%前後の值を示した。その後, 30 35msec まで右室の複雑な興奮波面と左室の break throughkよる左室前方と左後方への興奮 波面が形成され，Residueは $48 \%$ 前後まで上昇し

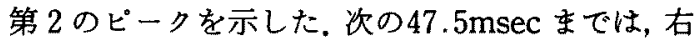
室の興奮波面と左室後壁の興奮波面は，共後方 に向かいResidueも12\%前後まで低下した．その 後は左室, 右室ともに右後方へ向かう興奮波面を 示し, Residueは $4 \%$ 前後の非常な低值となつた。 すなわち，臨床例との比較は困難ではあるが， Residueは二つのピークを形成し，臨床の正常例 と似たパターンを示した。

\section{2) 前壁梗塞}

図2で示されたようにシュュレーションモデ ルの左室の約 $1 / 4$ に相当する破線内の格子点を興 奮不能として前壁梗塞を設定した。 その結果を図 7 中央に示した. 左室興奮開始から $10 \mathrm{msec}$ では, 左室前壁側の興奮波面は正常の約半分に減少し Residue $7.0 \%$ と正常より低下した．次の 15.0 msec までは，興奮波面は中隔と側壁に分かれて 広がるためResidueは正常より高値を示した。 $17.5 \mathrm{msec} て ゙ は$ 右室の興奮が開始され，Residueは

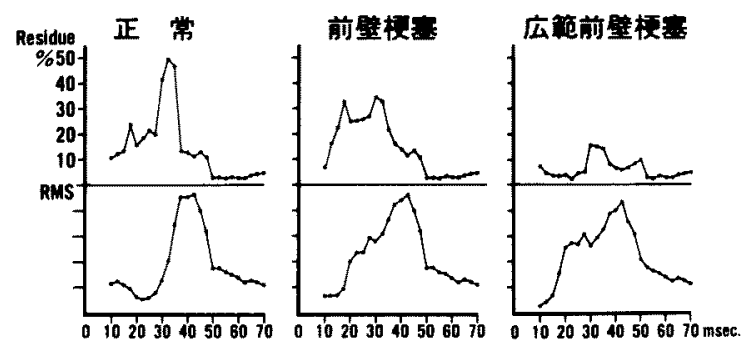

図 7.2 次元モデル

2 次元モデルでの各設定のResidue (上段) とRMS 電位 (下段) を示す. Residueは前壁梗塞設定では正常 に比し第 1 のピークの増大，第 2 のピークの減少を認 め，広範前壁梗塞設定では両ピークの减少を認めた。 
$33.1 \%$ 第 1 のピークを示した. 22.5 27.5msec では正常の左室興蝟波面は閉曲面であつたが, 梗 塞により前壁が興奮不能なため左室の興奮波面は 左後方へ向かい, 右室の 3 力所からの興䀢と共に

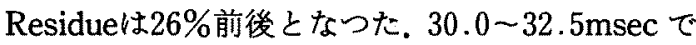
はResidueは再び上昇して第2のピークを形成す るが，正常ほど高值を示さず $34 \%$ 前後であつた。

これは左室壁が梗塞のため，両室の興奮波面が共 に後方に向かつたためと考古られた. $35.0 \mathrm{msec}$ 以後の興奮域は正常とほ注同様で, Residueも同 等の值を示した。

\section{3）広轮前壁梗塞}

図 2 で示された様に：シュミレーションモデル の左室の約 $1 / 2$ に相当する破線内の格子点を興奮 不能として広範前壁梗塞を設定した。その結果を 図 7 右に示した。左室の興奮は中隔側のみで開始 され右側方向への興奮波面を示し，Residueは $10 \%$ 以下の低值であつた． $17.5 \mathrm{msec} よ り$ 右室の 興奮も開始されるが，興奮波面が左室之同じ右側 方向のため, Residueは低值が続いた. その後, 30 $\mathrm{msec}$ より右室の右側方向の與奮波面と左室の後 方向への興奮波面が共存するため, Residueは 15\%前後まで上昇した. $36.0 \mathrm{msec}$ からは左室, 右 室とも右後方向への興奮波面となるため,

Residueは再び10\%以下まで低下し，42msec から は正常と同等のResidueを示した.

以上，心筋モデルは二次元レベルではあつたが， 梗塞による興奮波面の変化をResidue曲線上で捉 えることが出来た，前壁梗塞設定では臨床例と同 様, Residueは第 1 のピーク付近の $27.5 \mathrm{msec}$ は正常より1.20〜1.65倍の増大を示し，第 2 の ピーク付近の $35 \mathrm{msec}$ までに0.46 0.83倍の減少 を認めた. 広範前壁梗塞設定では, Residueは27.5 msec な゙に0.14〜0.68倍, $35 \mathrm{msec}$ な゙は 0.30〜0.37倍と非常な減少を示した。これらの所 見は, 20.0 27.5msec では正常の左室興奮波面 が閉曲面となるため相殺され，右室興奮波面が反 映されてResidueは20\%前後の值を示したが，梗 塞設定ではこの閉曲面が割れて新しい一つの興奮 波面となるためResidueに変化を及ぼしたと考え
られた。すなわち，前壁梗塞設定では左後方への 興奮波面が反映されてResidueは増大し，広範前 壁梗塞設定では右後方への興奮波面が反映されて Residueが減少したと考えられた. 30msec 以後で は，正常の左室興奮波面がbreak through し Residueは高值を示したが，前壁梗塞設定では前 壁中隔領域を興翼不能としたため，左室と右室の 興奮波面が比較的同一の後方向となり, Residue は正常に比し低值を示したと考えられた。このよ うに梗塞設定でる臨床例に似たパターンを認める ことができた。

\section{4）双極子の位置による計算誤差と Residue}

心缄内に実線で示される様な任意の双極子を仮 定し体表上の電位を計算，その値を用い我々の方 法で双極子の位置を計算すると，破線のような双 極子が得られResidueが求められた（図 8 ）。双極 子が心内の後方に位置すると仮定した際, 計算上 の双極子の位置はより後方にずれResidueは低值 を示すが，双極子の大きさに明らかな差を認めた。 これは双極子の位置が体表より後方に離れるに従 い, 計算精度が低下したためであろうと考えられ た，双極子が心内の左方に位置すると仮定した際

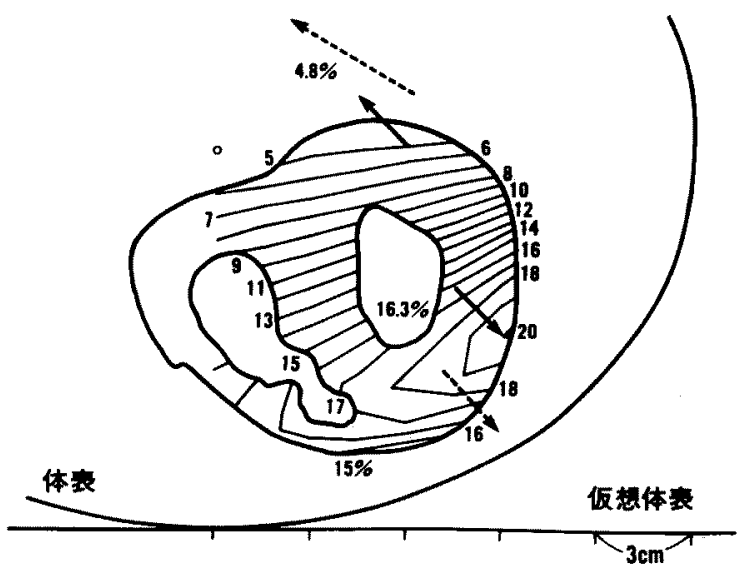

図 8，双極子の位置と残渣（\%)の分布 心筋モデル内に実線で示される様な任意の双極子を 仮定し体表上の電位を計算，その値を用い我々の方法 で双極子を計算すると，破線のような双極子が得られ 残渣(Residue)が求められた.すなわち，この残椬(\%) は本法の計算誤差を示し，双極子の位瞋による影謷を 受けていると考党られた。 
には，計算上の双極子の位置に明らかな差を認め Residueは高値を示した。これは楕円前面の誘導 点が，計算時に仮想体表上にあるとしたためであ ろらと考えられた。すなわち，図７で示した Residueが梗塞設定により正常より高値を示した のは，その時点での主双極子の位置が正常より側 方に移動していた可能性を示唆した. Residueが 正常より低値を示したのは，その時点での主双極 子の位置が正常より後方に移動していた可能性を 示唆した。臨床例の計算時にも前胸面を平面とし て計算しているため, Residueは同様の影響を受 けていると考学られた。しかし，この結果で分か るよらに双極子の位置による影響は，ごく一部を 除きResidueは20\%以下であつた。

\section{考案}

心臓電気現象を体表の電位から推定しようとす る, いわゆる逆問題解はコンピュータの発達と共 に，同時に多数の誘導から得られた電位を分析す ることで可能になつた，体表面電位図に表わされ る複雑性を定量的に表現する方法としては，多極

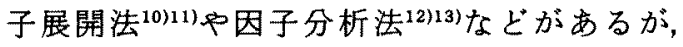
我々は単一双極子を瞬時ごとに求める single moving dipole法を用いた ${ }^{14)}$.さらに単一双極子で は近似し得なかつた非双極子成分を残渣 (Residue) として定量化し，正常者と陳旧性心筋 梗塞患者について比較検討した。この様な解析法 はMirvisがウサギの急性虚血実験で報告してい るが15), 臨床例はまだ他に発表されていない,我々 の方法では推定される主双極子の位置及び成分に よつて, Residueは計算上の影響を受けるが, 低值 を示す時は単一双極子性が高く，高值を示す時は 多双極子性が高いことを示唆している.

正常群ではQRSの前半中央 $22 \mathrm{msec} て ゙$ Residue は15.6\%の最低值を示し, 後半 $48 \mathrm{msec} て ゙ 27.6 \%$ とピークを示し, 以後, この程度の高值を持続し た。すなわち，QRSの後半に多双極子の存在が示 唆された。これは1963年のTaccardi ${ }^{11}$ の報告に一 致する。な报，彼の報告でQRS前半に認めた多双 極子性は, 我々の症例では図 3 左のQRS前半 20 msec にResidueのピークとして示されたが，その
時間帯は短く個々の症例により時間的ばらつきが あつたため, 平均のResidue曲線 (図 4 左)上では 明らかとはなりがたかつたと考えられた。

二次元心室興奮伝播シュミレーションの結果, Residue曲線は臨床例と同様のバターンを示し た.シュミレーションより臨床例の興奮波面を推 定すると，QRS初期のResidueのピークは右室興 舊開始のためであり，QRS中期以後のピークは左 室のbreak throughのためと考えられた。その間 のResidueが比較的低值を示したのは, 左室内の 興奮波面が閉曲面となり互いに相殺し合い, 右室 の興奮波面が主体となつたためと考えられた。

心筋梗塞患者では梗塞により興奮波面や伝導時 間にみだれが生じ16)17)，多双極子性，すなわら，高 いResidueを示すことが予測された。前壁梗塞群 ではQRSの前半中央18 -28msec でResidueは約 $24.3 \%$ と, 正常群の約 $16.2 \%$ に比しきわめて有意 な高值を示した $(\mathrm{p}<0.001)$. 二次元シュミレー ションでも20 25msec で, Residue は正常の 1.58〜1.20倍の高値を示した。広範前壁梗塞群で も18～22msec で正常群に比し有意な高値を示し $(\mathrm{p}<0.02)$ ，多双極子性が示唆された，この所見は Flowersら ${ }^{18)} の$ difference mapの実験で, 右室の break through直前で梗塞の大きさと最も良い相 関を示したといら報告と一致すると思われる.

一方，QRS中期では，広範前壁梗塞群の38 52 msec でResidueは約14.5\%と，正常群の約 $25.1 \%$ に比し非常に有意な低值を示した $(\mathrm{p}<0.01)$.二 次元シュミレーシェンです30〜35msec で, Residueは正常の0.30〜0.37倍の低値を示した. 前壁梗塞群でも同様の傾向があり, 単一双極子性 が示唆された。ささらに，梗塞の大きさと瞬時ごと のResidueとの相関を経時的に求めた結果, QRS 開始より $38 \mathrm{msec} て ゙ \mathrm{r}=-0.6381(\mathrm{p}<0.01)$ の最良 の負の相関が得られた。これはFlowersら ${ }^{19)}$ の臨 㦿例でのdeparture mapの検討で, $30 \sim 60 \mathrm{msec} に$ 異常所見を認めたという報告と一致すると思われ る。梗塞による単一双極子性の増大はシュミレー ションで示された様に, 本来は梗塞領域の興奮に よつて相殺されていた正常心筋の興奮が明らかに 
なつた事も一つの要因と考えられる，大きい梗塞 ほどQRS中期のResidueが低值を示し，単一双極 子性が高まる事は，モデルにも示されたように， 興奮し得る心筋領域が少なくなり興奮伝播過程が 単純化された事によると推察される。なた，臨床 的には，体表面電位分布よりResidueを求めるこ とによつて，心筋梗塞の大きさを推定できる可能 性が示された。

\section{結論}

1）正常者と陳旧性前壁心筋梗塞患者に打いて, 体表面電位図から求められた心室興奮過程の瞬時 の心双極子性を比較検討した。

2）前壁梗塞群では正常群に比し，QRSの $23 \pm 5$ msec で非単一双極子成分, 残湓は有意な高值を 示し $(p<0.001)$ 多双極子性が示唆された，広範 前壁梗塞群では正常群に比し，QRSの $45 \pm 7 \mathrm{msec}$ で, 残渣は有意な低值を示し $(\mathrm{p}<0.01)$ 単一双極 子性が示唆された。

3）二次元心室興䀢伝播シュミレーションでは, 梗塞による心双極子性の変化は残渣曲線上, 臨床 例と同様の傾向として表われ，本法の信頼性が確 かめられた。

4）心㬳梗塞の大きさと瞬時ごとの残渣の間に は, 38msec で最も良い負の相関が認められ $(\mathrm{r}=-0.6381, \mathrm{p}<0.01)$, 梗塞が大きいほど単一 双極子性が高いことが示唆され，本法により心筋 梗塞の大きさを推定できる可能性が示された。

\section{文献}

1) Taccardi B: Distribution of heart potentials on the thoracic surface of normal human sub. jects. Circ Res $12: 341,1963$.

2) Horan LG, et al : Body surface potential distribution: Comparison of naturally and artificially produced signals as analyzed by digital computer. Circ Res $13: 373,1963$.

3) Spack MS, et al: Body surface isopotential maps in normal children, ages 4 to 14 years. Amer Heart J 72:640, 1966.

4) Gabor D and Nelson CV: Determination of the resultant dipole of the heart from measurements on the body surface. J Appl Physics 25: $413,1954$.

5) Helm RA and Chou T: Computation of a variable location dipole representation from body surface leads. Amer Heart J 77 : 363, 1969.

6）綱川宏：体表面電位図上り求めた心双極子分析 の臨床的応用. 正常例の検討. 日内会誌 $72: 25$, 1983.

7) Teramachi $Y$, et al: Dynamic color display system of body surface potentials. Yamada $\mathrm{K}$, et al, ed: Advances in Body Surface Potential Mapping, University of Nagoya Press, Nagoya, 1983, p109.

8) Okamoto $Y$, et al: Moving multiple dipole model for cardiac activity. Jpn Heart J $23: 293$, 1982.

9) Durrer D, et al: Total excitation of the isolated human heart. Circulation $41: 899,1970$.

10) Geselowits DB: Multipole representation for an equivalent cardiac generator. Proc IRE 48 : $75,1960$.

11) Brody DA : The inverse determination of simple generator configurations from equivalent dipole and multipole information. IEEE Trans Bio-Med Eng BME-15 : 106, 1968.

12) Scher AM, et al: Factor analysis of the electrocardiograms. Test of electrocardiographic theory :Normal hearts. Circ Res $8: 519$, 1960.

13) Horan LG, et al: Pricipal factor waveforms of the thoracic QRS complex. Circ Res $15: 131$, 1964.

14) Mirvis DM, et al: Experimental comparison of four inverse electrocardiographic constructs in the isolated rabbit heart. J Electrocardiol $11: 57,1978$.

15) Mirvis DM: Electrocardiographic QRS changes induced by acute coronary ligation in the isolated rabbit heart. J Electrocardiol 12 : $141,1979$.

16) Daniel TM, et al: Comparison of human ventricular activation with a canine model in chronic myocardial infarction. Circulation 44 : 74, 1971.

17) Elharrav V and Zipes DP: Cardiac electrophysiological alterations during myocardial ischemia. Levy MV and Vassalle Med : Excitation and Neural control of the heart. Amer Physiol Society, Maryland, 1982, p149.

18) Flowers NC, et al: Surface reflections of cardiac excitation and the assessment of infarct volume in dogs. A comparison of methods. Circ Res 43: 406, 1978.

19) Flowers NC, et al: Anterior infarctional changes occurring during mid and late ventricular activation detectable by surface mapping thchniques. Circulation 54 : 906, 1976. 